\title{
Root Cause Analysis for Identifying Defects in the Process of Cylinder Head Castings from Aluminium Alloy
}

Kalincová Daniela, Ťavodová Miroslava, Čierna Helena

Faculty of environmental and manufacturing technology, Technical university in Zvolen, Študentská 26, 96053 Zvolen

Slovak Republic.E-mail: daniela.kalincova@tuzvo.sk, miroslava.tavodova@tuzvo.sk, cierna@tuzvo.sk

The research into root causes of defects in cylinder head castings are described in the paper. Chemical composition of castings, evaluation of casting microstructure before and after the heat treatment and final inspection of casting quality from various points of view are parts of the research. The list of the most common defects in case of using five selected products is the result of the experiment. The objective of the research was to identify causes of defects in the process of cylinder head casting as well as to identify root causes of discrepancy using the quality management tool.

Keywords: cylinder head, casting, defect, management quality tools.

\section{References}

[1] BOLIBRUCHOVÁ, D., TILLOVÁ, E., (2005). Zlievárenské zliatiny AlSi, Žilinská univerzita v Žiline 2005, ISBN 80-8070-485-6.

[2] BOLIBRUCHOVÁ, D., RICHTÁRECH, L. (2013). Study of the gas content in aluminum alloys, In: Manufacturing technology, Vol. 3, No. 1, ISSN 1213-2489, pp.14-20.

[3] ČIERNA, H., ŤAVODOVÁ, M. (2013). Using the Design of Experiment Method to Evaluate Quality of Cuts after Cutting Aluminum Alloy by AWJ, In: Manufacturing technology 2013, Vol. 13, No. 3, ISSN 12-13-2489, pp.303307.

[4] ELBEL, T. (1992). Vady odlitků se zlitin železa, Matecs Brno 1992

[5] GEJDOŠ, P., ŠATANOVÁ, A., SIMANOVÁ, L', KRAJČíROVÁ, L. (2010). Practical implementation of 5S method for conditions of selected enterprise. In „Engineering and quality production“. Zborník z MVK publishing by Dnipropetrovsk, 2010, ISBN 978-966-1507-34-9, pp. 49-60.

[6] HRICOVÁ, J. (2013). Influence of Cutting Tool Material on the Surface Roughness of AlMgSi Aluminium Alloy In: Manufacturing technology 2013, Vol. 13, No. 3, ISSN 12-13-2489, pp. 324-329.

[7] MICHNA, Š., LUKÁČ, P. (2003). Barevný kontrast, struktury a vady u hliníku a jeho slitin, Delta Print Děčín, 2003

[8] MICHNA, Š., NÁPRSTKOVÁ, N. (2012). Research into the causes cracking of aluminium alloys of Al - Cu during mechanical machining. In: Manufacturing Technology, Vol. 12, 2012, ISSN 1213-2489, pp. 47-51.

[9] MILATOVÁ, P. (2012). Kvalita odliatkov hláv valcov - chyby odliatkov a ich experimentálne hodnotenie: diplomová práca. Zvolen: Technická univerzita vo Zvolene. Fakulta environmentálnej a výrobnej techniky. 2012.

[10]TILlová, E., CHAlupovÁ, M., HURTAlOVÁ, L., ĎURINÍKOVÁ, E. (2011). Quality control of microstructure in recycled Al-Si cast alloys. In. Manufacturing Technology, Vol. 11, No. 11, ISSN 1213-2489, pp. 70-76. 